\title{
On the Raising and Control of Modal Auxiliary Verbs
}

\author{
Bo Hu (Corresponding author) \\ Faculty of Humanities and Social Sciences, City University of Macau \\ Taipa, Macao \\ E-mail: hubo@cityu.mo
}

Hong Chen

Faculty of International Tourism and Management, City University of Macau

Taipa, Macao

Received: July 11, 2020

Accepted: August 13, 2020

Published: August 27, 2020

doi:10.5296/ijl.v12i4.17595

URL: https://doi.org/10.5296/ijl.v12i4.17595

\begin{abstract}
Modal auxiliary verbs are a type of verb that expresses the speaker's attitude and opinion towards a proposition or an event. This paper investigates the syntactic features of modal auxiliary verbs in different languages from the aspects of semantic constraints, the deletion of complement clauses, constituent movement, pseudo-cleft construction and temporal and aspect markers, and analyzes relevant hypotheses of modal auxiliary verbs under the framework of generative grammar. We challenge the assumption that modal verbs are raising verbs, argue that modal auxiliary verbs should be analyzed as raising or control verbs.
\end{abstract}

Keywords: Modal auxiliary verbs, Syntactic features, Raising, Control

\section{Introduction}

According to Lyons (1977) and Palmer (2001) et al., modal auxiliary verbs (MAV) are concerned with the speaker's opinion or attitude towards the proposition or event, which mainly includes three types of MAV: epistemic, deontic and dynamic. For example:

(1) a. John must be sick.

b. John should apologize.

c. John can make cakes by himself. 
The epistemic MAV must in (1a) have to do with the estimation of the chances that John is sick. The deontic MAV should in (1b) has to do with the degree of moral desirability of John apologize. The dynamic MAV can in (1c) describes John's ability to make cakes by himself. The syntactic and semantic features of these three types of MAV are well-studied in recent 50 years. The early studies of MAVs believe that epistemic MAVs are intransitive raising verbs and root MAVs (deontic MAVs and dynamic MAVs) are transitive control verbs. In (1a), must is an intransitive verb followed by an infinitive clause, and the matrix subject John is raised from the complement infinitive clause John be sick. The subject of epistemic MAV can be both animated and unanimated. In (1b-1c), root MAVs, should and can, are transitive verbs whose subject must be animated and coindex with the null subject of the complement clause.

However, Pullum \& Wilson (1977), Wurmbrand (1999), Eide (2002), et al believe that MAVs are all raising verbs since deontic MAVs can be intransitive. For example:

(2) a. There may be beer and cider at the party, but I refuse to permit spirits in the house.

b. There must be no punching below the belt, and no throttling.

(Pullum and Wilson, 1977)

In (2), expletive subject there is the subject of be and raises to the subject position of MAVs may/must which are deontic modals. They also point out that dynamic MAVs like dare/will which need an animated subject also can be shifting into intransitive uses, and these MAVs can license an unanimated subject. For example:

(3) a. These two aspects of death cannot be successfully separated, but they dare not be confused or identified.

b. Inflation is a problem which dare not be neglected.

(Pullum and Wilson, 1977)

Wurmbrand (1999) further claims that deontic MAVs do not assign a subject theta-role and these roles are assigned contextually. He points out that thematic relations in deontic constructions are not theta-roles and there is no mapping between theta roles and syntactic arguments in deontic modal constructions. For example:

(4) The traitor must die.

In (4), the "oblige" of must can't be assigned to its subject, the traitor, but somebody determined in the context. What's more, he points out that in Icelandic modal constructions retain the quirky case which indicates that deontic MAVs are raising verbs. For example:

(5) a. Haraldi/*Haraldur verður að lika hamborgarar.

Harold-DAT/ Harold-NOM must to like hamburgers

'Harold must like hamburgers (to be accepted by his new American in-Laws).'

b. Umsækjandann verður að vanta peninga. 
The-applicant-ACC must to lack money

'The applicant must lack money (to apply for this grant).'

(Wurmbrand, 1999)

In (5), lika/vanta is verbs that require a quirky case subject, and deontic MAV verður retains a quirky case subject. But we can not conclude that all MAVs are raising since there is no evidence indicating dynamic MAVs are raising verbs. According to Thráinsson \&Vikner (1995), dynamic MAVs in Icelandic don't collocate with such verbs which require a quirky case subject.

(6)

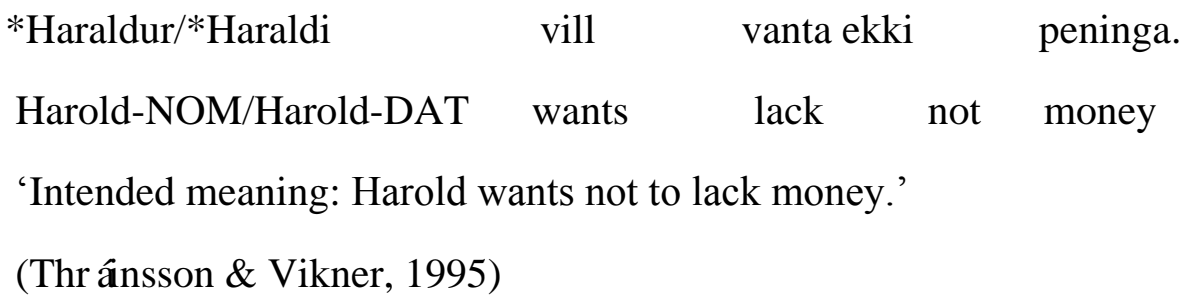

Since the hypothesis that MAVs are raising verbs isn't without a problem, many other linguists like Zubizarreta(1982), Roberts(1985), Brennan (1993), Thráinsson \&Vikner (1995), LØdrup (1996), Drubig (2001), Asarina \& Holt (2005), Hu(2015), et al. believe that MAVs should be analyzed as raising or control verbs. They all agree that epistemic MAVs are raising verbs and dynamic MAVs are control verbs.

As for the deontic MAVs, Brennan (1993) and Asarina \& Holt (2005) believe that there are two types of deontic MAVs: direct and indirect, indirect deontic MAVs are raising verbs and direct deontic MAVs are control verbs. Brennan proposes that direct deontic MAVs can assign theta role to the subject and are control verbs, while indirect deontic MAVs are raising verbs and can't assign theta roles. For example:

(7) a. The man must disappear.

b. The bread must disappear.

(7a) is ambiguous and must can be analyzed as direct or indirect deontic MAV. While must in (7b) can only be an indirect deontic MAV. The difference is that the subject of direct deontic MAVs can be theta-marked and is animated; while indirect MAV can't, so unanimated subjects are possible. Wurmbrand (1999) points out that, even in deontic MAV constructions with an animated subject, there is no direct interpretation showing theta-roles like 'obligee' or 'permissee' to coincide with a specific syntactic argument in the sentence, and these theta roles are assigned contextually. For example:

(8) The old man must fall down the stairs and it must look like an accident.

Wurmbrand believes that the modal force in (8) is not applied to the subject of the sentence but someone else, that is, someone has the obligation to bring about the situation that the old man falls down the stairs. 


\section{Macrothink}

International Journal of Linguistics

ISSN 1948-5425

2020, Vol. 12, No. 4

The debate on the raising or control of MAVs has attracted many linguists' attention these years and there is still no set answer for it. In this paper, we try to answer the following questions:

1) What are the syntactic differences among epistemic, deontic and dynamic MAVs?

2) Are all MAVs raising verbs? If not, what hypotheses can explain the syntactic features of MAVs in different languages?

This paper is organized as follows. Section one is the syntactic features between epistemic and dynamic MAVs. In line with recent studies, we believe that epistemic MAVs are raising verbs and the subject of epistemic MAVs is obligatorily raised to value its case feature; dynamic MAVs are control verbs and the null subject PRO in the embedded clause is coindexed with the subject of the main clause. Section two is the syntactic differences between direct and indirect deontic MAVs. The indirect deontic MAVs are raising verbs and their subjects are not semantically constrained, while the direct deontic MAVs are control verbs and their subjects should be animated. Section three is the syntactic hypotheses of MAVs. The unified raising hypothesis of MAV also is not without problem, and a raising and control hypothesis under the Minimalist Program is assumed. Some relevant problems are discussed in section four.

\section{Differences Between Epistemic MAVs and Dynamic MAVs}

\subsection{Semantic Constraints}

Epistemic MAVs do not constrain the semantic features of the subject, while dynamic MAVs do select an animated subject.

(9) a. Maten må/skal/kan serveres snart. (epistemic)

The food must/will/may serves soon

'The food must/will/may be served soon'

b. *Maten vil/kan bli $\quad$ servert snart. (dynamic)

The food will/be able to serve soon

'Intended meaning: The food will/be able to be served soon.'

(Norwegian, Eide, 2002: 116)

We see in (9a) that the subject of epistemic MAVs can be unanimated. Whereas the sentence of dynamic MAVs with an unanimated subject is unacceptable. The requirement of an animated subject in the dynamic MAV clause is common in different languages. In Icelandic, MAVs with the expletive subject there can only be interpreted as epistemic, not dynamic, as shown in (10). In Tagalog, the dynamic MAVs with an unanimated subject will be unacceptable, as shown in (11). 
(10)a. Der vil komme ti studenter til foredraget.

There will come ten students to the talk

'Ten students will come to the talk.'

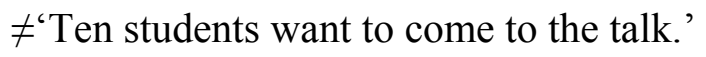

b. Pað kunna að hlusta tíu stúdentar á fyrirlesturinn.

There can to listen ten students to talk-the

'Ten students may listen to the talk.'

$\neq^{\prime}$ Ten students are able to listen to the talk.'

(Tagalog, Thráinsson \& VIkner, 1995)

$\begin{array}{cccccc}\text { (11)a. Kaya } & \text { ng } & \text { lalaki } & \text { bumili } & \text { ng } & \text { kotse. } \\ \text { Can } & \text { NG } & \text { man } & \text { SA-buy } & \text { NG } & \text { car }\end{array}$

'The man can buy a car.'

b. *Kaya ng tinapay mawala.

Can NG bread disappear

'Intending meaning: The bread is able to disappear.'

(Icelandic, Asarina \& Holt, 2005)

In (10), vil can only be interpreted as epistemic 'will', but not its other meaning 'want', and kunna which means 'may' and 'be able to' can only be interpreted as epistemic 'may'. In (11), dynamic MAV kaya can only license an animated subject, but never an unanimated subject.

When it comes to polysemic MAVs, their meaning will be identified according to the animacy of the subject. In Mandarin Chinese, when a MAV has both epistemic and dynamic interpretation, only its epistemic interpretation can license an unanimated subject. For example:

$\begin{array}{cccl}\text { (12)a. 张三 } & \text { 会 } & \text { 说 } & \text { 中文. (dynamic) } \\ \text { Zhangsan } & \text { hui } & \text { shuo } & \text { zhongwen. } \\ \text { Zhangsan } & \text { can } & \text { speak } & \text { Chinese } \\ \text { 'Zhangsan can speak Chinese.' } & \\ \text { b. *会议 } & \text { 会 } & \text { 结束. (dynamic) } \\ \text { huiyi } & \text { hui } & \text { jieshu. } \\ \text { meeting } & \text { can } & \text { over }\end{array}$




\section{Macrothink}

(13)a. 下个月

$$
\text { 张三 会 完成 }
$$

这个项目. (epistemic)

$\begin{array}{llccc}\text { xiageyue } & \text { Zhangsan } & \text { hui } & \text { wancheng } & \text { zhegexiangmu. } \\ \text { next month } & \text { Zhangsan } & \text { will } & \text { complete } & \text { this project }\end{array}$

'Zhangsan will complete this project next month.'

$\begin{array}{llllc}\text { b. 下个月 } & \text { 活动 } & \text { 会 } & \text { 如期 } & \text { 举行. (epistemic) } \\ \text { xiageyue } & \text { huodong } & \text { hui } & \text { ruqi } & \text { juxing. } \\ \text { next month } & \text { activity } & \text { will } & \text { schedule } & \text { hold }\end{array}$

'The activity will be held as scheduled next month.'

In (12), hui is interpreted as a dynamic MAV and its subject can only be animated. While in (13), hui is interpreted as an epistemic MAV and its subjects can be both animated and unanimated. This can be further testified in the MAV yao as in (14).

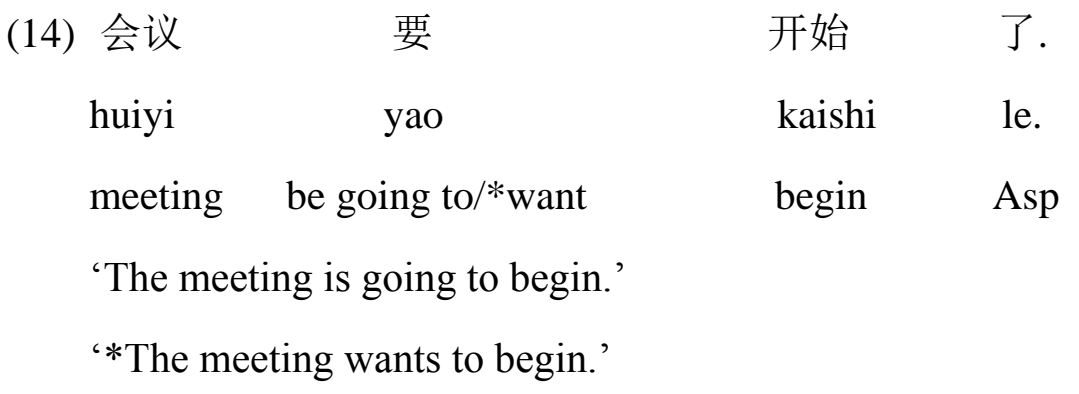

In (14), yao can only be interpreted as an epistemic MAV 'be going to' since its subject huiyi 'meeting' is unanimated, and the dynamic interpretation of yao 'want' is unacceptable. But why are there dynamic MAVs with an unanimated subject as in (3)? Recited as follows:

(15) a. These two aspects of death cannot be successfully separated, but they dare not be confused or identified.

b. Inflation is a problem which dare not be neglected.

In (15a), the grammatical subject of dare is they, which tends to be interpreted as an animated pronoun. Though the logical subject of dare is these two aspects of death, using the pronoun they to refer to these two aspects of death will trigger out the animation of the subject, a kind of personification. However, the passive construction will render the anaphora back to its in animation. This leads to the syntax-semantics mismatch phenomena. When we use an unanimated subject as the subject of dare, the sentence will be odd.

(16)These two aspects of death dare not be confused or identified.

Though replacing the relative pronoun which in $(15 \mathrm{~b})$ with the logical subject inflation also seems to be odd as in (17), the cause of it is different from (15a) and is still unclear to us.

(17)Inflation dare not be neglected. 


\section{Macrothink}

To sum up, epistemic and dynamic MAVs differ from each other in the semantic selection of their subject, that is, epistemic MAVs can license animated or unanimated subjects, while dynamic MAVs can only license animated subjects. The distinction between epistemic and dynamic MAVs also lies in the deletion and movement of the complement clause of these verbs.

\subsection{Deletion and Movement of the Complement Clause}

The deletion of complement clauses in dynamic MAV construction is legal, while it is ungrammatical in epistemic MAV construction. For example:

(18)a. Tom can drive a truck, and I can too.

b. Tom will do Jane a favor, and I will too. (will means 'be willing to'.)

(19)a. *Tom might have overheard them, and Mary might too.

b. *Tom must have finished his job, and Mary must too.

In (18), the deletion of complement clauses drive a truck/do Jane a favor is quite acceptable in dynamic MAV constructions of can/will. While the deletion of complement clauses have overheard them/have finished his job in (19) is ungrammatical in epistemic MAV constructions of might/must. It is also true in Chinese. For example:

$\begin{array}{rlrllll}\text { (20)a. 小明 } & \text { 肯 参加 } & \text { 这次 } & \text { 比赛, } & \text { 小李 } & \text { 也 } & \text { 肯. } \\ \text { Xiaoming } & \text { ken canjia zheci } & \text { bisai, } & \text { Xiaoli } & \text { ye } & \text { ken. } \\ \text { Xiaoming } & \text { be willing to take part in this } & \text { game, } & \text { Xiaoli } & \text { also } & \text { be willing to }\end{array}$

'Xiaoming is willing to take part in this game, and so does Xiaoli.'

b. 张三 会 开车, 李四 也 会.

Zhangsan hui kaiche, Lisi ye hui.

Zhangsan can drive Lisi also can

'Zhangsan can drive and so can Lisi.'

(21)a. *小明 可能 已经 毕业 了, 小李 也 可能.

Xiaoming keneng yijing biye le, Xiaoli ye keneng.

Xiaoming may already graduate ASP, Xiaoli also may

'Intending meaning: Xiaoming may have already graduated, and so may Xiaoli.'

b. *张三 应该 去了 上海, 李四 也 应该.

Zhangsan yinggai qu le Shanghai, Lisi ye yinggai.

Zhangsan must go ASP Shanghai, Lisi also must

'Intended meaning: Zhangsan must go to Shanghai, and so does Lisi.' 


\section{Macrothink}

In (20) and (21), the difference in epistemic and dynamic MAV constructions is manifested in the deletion of complement clauses in Chinese. What's more, ye 'also' in Chinese is an adverb, so the deletion of the complement clause with the dynamic MAV is ungrammatical.

(22)a. 小明 肯 参加这次 比赛, 小李 $*$ (肯).

Xiaoming ken canjia zheci bisai, Xiaoli ye ken.

Xiaoming be willing to take part in this game, Xiaoli also be willing to

'Xiaoming is willing to take part in this game, and so does Xiaoli.'

b. 张三 会 开车, 李四 也 $*$ (会).

Zhangsan hui kaiche, Lisi ye hui.

Zhangsan can drive Lisi also can

'Zhangsan can drive and so can Lisi.'

Dynamic MAV constructions not only distinct from epistemic MAV constructions in the deletion of complement clause of MAVs, but also in the movement of the complement clause to the front of the sentence. For example:

(23)a. 小明

肯

参加

这次

比赛.

Xiaoming ken

canjia

zheci

bisai.

Xiaoming be willing to

take part in

this

game

'Xiaoming is willing to take part in this game.'

b. 参加 这次比赛 小明肯.

canjia zheci bisai Xiaoming ken

take part in this game Xiaoming be willing to

'Xiaomign is willing to take part in this game.'

(24)a. 小明 可能已经毕业层

Xiaoming keneng yijng biye le

Xiaoming may already graduate ASP

'Xiaoming may have already graduated.'

b. *已经 毕业了明 可能.

yijng biye le Xiaoming keneng

Already graduate ASP Xiaoming may

'intended meaning: Xiaoming may have already graduated.' 


\section{IIMacrothink}

In (23), the raising of complement clause of dynamic MAV ken 'be willing to' is quite acceptable, but the raising of complement clause of epistemic MAVs like keneng 'may' is ungrammatical in (24). In English, the raising of the complement clause of MAVs also shows the difference between dynamic and epistemic MAV constructions.

(25)a. sing this song, Nancy can.

b. help me, Nancy will.

(26)a. *have overheard them, Nancy might.

b. *have completed the project, Nancy must.

What's more, the raising complement clause can also be replaced by adverb so in English, and the order of subject and MAV will be reversed. But it still shows the distinction between dynamic and epistemic constructions.

(27)a. Nancy can sing this song, and so can I.

b. Nancy will help me, and so will Tom.

(28)a. *Nancy might have overheard them, and so might I.

b. *Nancy must have completed the project, and so must I.

\subsection{Pseudo-Cleft Sentence}

What's more, epistemic and dynamic MAVs differ in complement clause focalization. The complement clause of epistemic MAVs can not be focalized and be transformed into the pseudo-cleft construction, while that of dynamic MAVs can.

(29)a.*What she definitely may is (to) be in London now.

b. What you definitely can do is finish the pie.

(Davidsen-Nielsen, 1990: 25)

In (29), the focalizing of the complement clause of the epistemic MAV may in English is unacceptable but that of the dynamic MAV can is acceptable. It is also true in Icelandic and Chinese as show in (30) and (31).

$\begin{array}{ccccccc}\text { (30)a. Eitt af pvi } & \text { sem } & \text { hann } & \text { kann } & \text { ekki } & \text { er að } & \text { synda. } \\ \text { One of it } & \text { that } & \text { he } & \text { can } & \text { not } & \text { is to } & \text { swim. }\end{array}$

'one of the things he cannot (do) is to swim.'

$\begin{array}{llllll}\text { b. *Dað } & \text { sem mig } & \text { vill } & \text { er að } & \text { vanta } & \text { peninga } \\ \text { It } & \text { that I } & \text { will } & \text { is to } & \text { lack } & \text { money }\end{array}$

'Intended meaning: What I tend to be is to be short on money.'

(Icelandic, Thráinsson \& Vikner, 1995: 61) 


\section{$\Delta$ Macrothink}

$\begin{array}{rccccccc}\text { (31)a. 去 } & \text { 上海 } & \text { 是 } & \text { 张三 } & \text { 所 } & \text { 不 } & \text { 肯 } & \text { 的. } \\ \text { qu } & \text { Shanghai } & \text { shi } & \text { Zhangsan } & \text { suo } & \text { bu } & \text { ken } & \text { de. } \\ \text { Go } & \text { Shanghai } & \text { is } & \text { Zhangsan } & \text { SUO } & \text { not } & \text { want } & \text { DE }\end{array}$

'What Zhangsan doesn't want is to go to Shanghai.'

\begin{tabular}{|c|c|c|c|c|c|c|c|}
\hline b. *已经 & 去 & 了 & 上海 & 是 & 张三 & 所 & 可能 \\
\hline yijing & qu & le & Shanghai & shi & Zhangsan & suo & keneng \\
\hline already & go & ASP & Shanghai & is & Zhangsan & SUO & possible \\
\hline
\end{tabular}

'Intended meaning: What Zhangsan is likely to do is have gone to Shanghai.'

\subsection{Aspect Auxiliary}

In many different languages, epistemic and dynamic MAVs are also distinct from each other in their collocation with aspect auxiliary. For instance, in Norwegian, MAV with perfective complement can only be interpreted as epistemic, while MAV can only be interpreted as dynamic when they are the complement of perfective MAVs.
(32) Han
vil/kan/må/skal
ha dreiet håndtaket.
He $\quad$ will/may/must/is
said to have turned the lever
(33)Han har villet/kunnet/måttet/skullet
dreie håndtaket.
He has want-to/can/must/shall-PRF
turn the-lever

(Dyvik, 1999)

Such distinction also exists in other languages, such as Chinese and Jambi. According to Lin (2011), MAV can only be interpreted as epistemic when their semantic scope is higher than the sentential aspect auxiliary le.

$\begin{array}{cccc}\text { (34) 张三 } & \text { 应该 } & \text { 毕业 } & \text { 了. } \\ \text { Zhangsan } & \text { yinggai } & \text { [biye } & \text { le]. } \\ \text { Zhangsan } & \text { must } & \text { graduate } & \text { ASP }\end{array}$

'it is a sure thing that Zhangsan have graduated.'

In (34), the semantic scope of MAV yinggai 'must' is higher than the aspect auxiliary le, and can only be interpreted as an epistemic MAV. But the semantic scope of the dynamic auxiliary is lower than the aspect auxiliary le as in (35).
(35) 张三
会
开车
了.

$\begin{array}{cccc}\text { Zhangsan } & \text { [[hui } & \text { kaiche }] & \text { le]. } \\ \text { Zhangsan } & \text { can } & \text { drive car } & \text { ASP }\end{array}$


'Zhangsan has learned to drive.'

In Jambi, MAV biso can only be interpreted as dynamic or deontic when its semantic scope is lower than aspect auxiliary la or lagi. It can be interpreted as epistemic when its semantic scope is higher than la or lagi.
(36)a. Maria la
biso yambe?
baranjo
Maria PECT
can ACT-take
thing-3

'Maria has been able to take her stuff.'

'Maria has been permitted to take her stuff.'

$\begin{array}{lcll}\text { b. Maria biso } & \text { la } & \text { yambe? } & \text { barayjo } \\ \text { Maria can } & \text { PECT } & \text { ACT-take } & \text { thing-3 }\end{array}$

'it is possible that Maria has taken her stuff.'

(37)a. Oran-tu

lagi biso datay

Person-DEM.DIST

PROG can come

'They currently are able to come.'

'They are being permitted to come.'
b. Oray-tu
biso lagi
datan

\section{Person-DEM.DIST can PROG come}

'it is possible that they are coming.'

(Yanti, 2011)

To sum up, epistemic MAVs differ from dynamic MAVs systematically in semantic constraint, deletion and movement of complement clause, pseudo-cleft construction and aspect auxiliary. Following the previous studies, such distinction can be explained when they are in different syntactic categories, that is, raising and control. Epistemic MAVs are raising predicates. They do not assign an external theta-role, and their only argument is a proposition as shown in (38).

(38)May: $\langle\varnothing\rangle\langle$ proposition $>$

So the subject position of clauses which include an epistemic MAV can be occupied by a subject moved from the complement clause, as in (39a), or by the expletive, as in (39b).

(39)a. Tom may [t like Mary].

b. It may be that Tom likes Mary.

The subject Tom in (38a) is the external argument of the verb of complement clause like, and is assigned an Agent role. According to Chomsky (2008[1995]), because the complement 
clause is nonfinite and nonfinite functional head $\mathrm{T}$ includes either [Plural] or [person], the case of Tom is not checked. To check the case, the subject Tom then raises to the subject position of the root clause. Since the root clause is finite, the subject Tom can check its case. When the raising is prevented from taking place in which the complement clause is finite and the subject Tom can check its case, the expletive it is inserted in the subject position of the root clause to satisfy EPP as in (38b).

While in Icelandic, the situation will be slightly different. The case-driven raising cannot explain the quirky case phenomenon which shows that the subject of the complement clause has checked its case in its complement clause with a quirky case verb as in (5). Repeated here:

(40) Haraldi/*Haraldur verður að lika hamborgarar.

Harold-DAT/ Harold-NOM must to like hamburgers

'Harold must like hamburgers (to be accepted by his new American in-Laws).'

In (40), the subject Haraldi has already checked it quirky case in the embedded non-finite clause with a quirky case verb lika, but it still moves to the subject position of the root clause. So we assume that the subject raising is not driven by case requirement but by EPP. It can be further testified in Chinese raising modal constructions. For example:

$\begin{array}{rccccc}\text { (41)a. 可能 } & \text { 张三 } & \text { 已经 } & \text { 去 } & \text { 北京 } & \text { 了. } \\ \text { Keneng } & \text { Zhangsan } & \text { yijing } & \text { qu } & \text { Beijing } & \text { le. } \\ \text { possible } & \text { Zhangsan } & \text { already } & \text { go } & \text { Beijing } & \text { ASP }\end{array}$

'Zhangsan may have already gone to Beijing.'

$\begin{array}{llllll}\text { b. 张三 } & \text { 可能 } & \text { 已经 } & \text { 去 } & \text { 北京 } & \text { 了. } \\ \text { Zhangsan } & \text { Keneng } & \text { yijing } & \text { qu } & \text { Beijing } & \text { le. } \\ \text { Zhangsan } & \text { Possible } & \text { already } & \text { go } & \text { Beijing } & \text { ASP }\end{array}$

'Zhangsan may have already gone to Beijing.

In (41), the complement subject Zhangsan is not obligatory to raise to the subject position of root clause, the sentence is acceptable. According to Lin (2011), the subject Zhangsan has checked its case in the finite complement clause. So we assume that there is a null expletive in (41a) to satisfy EPP, and the raising of Zhangsan in (41b) is not driven by EPP but by some other regulation such as Topicalization. If the complement clause is non-finite, the raising of complement subject will be obligatory, as shown in (42).

$\begin{array}{clll}\text { (42)a. *会 } & \text { 张三 } & \text { 去 } & \text { 北京. } \\ \text { Hui } & \text { Zhangsan } & \text { qu } & \text { Beijing. } \\ \text { will } & \text { Zhangsan } & \text { go } & \text { Beijing }\end{array}$




\section{Macrothink}

'intending meaning: Zhangsan will go to Beijing.'

b. 张三 会三北京.

Zhangsan hui qu Beijing.

Zhangsan will go Beijing

'Zhangsan will go to Beijing.

In (42a), the complement subject Zhangsan cannot check its case in the complement clause, so the sentence is ungrammatical. Only when it raises to the subject position of root clause driven by EPP and checks its case, the sentence can be acceptable, as in (42b).

Dynamic MAVs like will and dare are control verbs whose external argument should be animated, as shown in (43).

(43) Will/dare: <+animated>, <non-finite clause>

So the subject of dynamic MAVs will be the controller, which co-indexes with the empty subject of nonfinite complement clause PRO. For example:

(44)a. Tom will [PRO help his classmates].

b. The hunter dare [PRO shoot a tiger].

Normally, the sentences with an unanimated subject of dynamic auxiliary construction will be abnormal and unacceptable, as in (44).

(45)a. *The bread will eat me.

b. *The stone dare shoot a tiger.

However, Pullum and Wilsom (1977) point out that there are sentences with unanimated subjects of dynamic MAVs. But all these so-called unanimated subject sentences in their studies are all passive and negative, and the active or positive of these sentence constructions will be quite unacceptable. For example:

(46)a. *These two aspects of death dare be clear enough.

b. *Inflation dare be over.

(47)a. *These two aspects of death dare be confused or identified.

b. *Inflation dare be neglected.

So the examples cited by Pullum and Wilsom (1977) are special cases that can only be interpreted as a syntax-semantics mismatch. The raising and control analysis of epistemic and dynamic MAVs is no doubt the proper assumption to understand the syntactic characteristics of MAVs. 


\section{The Syntax of Deontic MAVs}

The syntactic category of deontic MAVs has been controversial for many years. Some researchers believe that there is no semantic constraint in the subject of deontic MAVs that belongs to raising verbs. In the northern dialect of Italia, deontic MAVs can not only occurs sentence-initially but also license the expletive subject it.
(48)a. Bisugne
ch'al
vae.
It-is-necessary
that
he-go
b. El vole magna.
It wants eaten
'it is necessary to eat it.'
(Beninca and Poletto, 1994)

In English, the subject of deontic MAVs can be expletive there or unanimated subject. For example:

(49) a. There may be singing but no dancing on my premises.

b. There can be a party as long as it's not too loud.

(50) a. The biscuits may be finished by Paul.

b. An opening hand must contain thirteen points.

c. Icicles may hang from the eavestroughs.

(Wurmbrand, 1999)

In Norwegian, deontic MAVs can license expletive subject there, weather-it subject and unanimated subjects.

(51) a.Det skal bestandig være mist to voksne til stede.

There shall always be at-least two adults at place

'There should always be at least two adults present.'

b. Nå bØr det snart regne; gresset er så tØrt.

Now should it soon rain the-grass is so dry

'It ought to rain soon; the grass is so dry.'

c. Maten må/skal/kan/bØr bli server snart.

'The food must/will/may/should be served soon (epistemic/root=OK)'

(Eide, 2002: 80) 


\section{Macrothink}

International Journal of Linguistics

ISSN 1948-5425

2020, Vol. 12, No. 4

In a nutshell, deontic MAVs allow unanimated subject or expletive subject, and there is no semantic restriction for the subject of deontic MAVs. What's more, they can occur sentence-initially, which indicates the transitivity of these verbs. All these syntactic features are similar to epistemic MAVs. Then it seems we can assume that deontic MAVs are raising verbs which takes a proposition as its complement. But deontic MAVs differ from epistemic MAVs in syntactic features such as complement deletion and move. Ross(1969) points out that, in German, when a MAV can be used either as deontic or epistemic, only the verb with deontic interpretation allows the deletion of complement constituents while the verb with epistemic interpretation can't.

(52) a. Ottokar muss singen, und du musst es auch/das musst du auch. (deontic)

Ottokar must sing and you must it too you must you too

'Ottokar must sing and you must (it) too.'

b. *Ottokar muss krebs haben, und du musst es auch/das musst du auch. (epistemic)

Ottokar must have cancer, and you must it too you must you too

This difference in MAValso exists in English (Drubig, 2001:30), Indonasia (Fortin, 2012:14) and Turkish (Aelbrecht, 2009:52).

(53) a. John must wash his car every day and Peter must too. (deontic)

b. *John must wash his car every day and Peter must too. (epistemic)

(54) a. Saya tidak mau latihan piano, tapi saya mesti.

1SG NEG want practice piano but 1 SG must

'I do not want to practice piano, but I must.'

b. Siti selalu bekerja. Dia bilang dia tidak capai, tapi saya pikir dia pasti *(capai).

Siti always work 3SG say 3SG NEG tired, but ISG think 3SG certain tired

'Siti is always working. She says she's not tired, but I think she must be tired.'

(Indonasia)

(55) a. Jessica wil niet gaan werken morgen, maar ze moet.

Jessica wants NEG go work tomorrow but she must

'Jessica doesn't want to go to work tomorrow, but she has to.'

b. Arne zegt dat hij niet de hele taart heft opgegeten, maar hij moet wel *(de hele tart)

Arne says that he NEG the whole pie has up.eaten but he must PRT the whole pie

hebben opgegeten, want ze is weg.

Have up.eaten for she is away 
'Arne says that he didn't eat the whole pie, but he must have, for it's gone.'

(Turkish)

Furthermore, the movement of complement constituents of deontic MAVs is possible, while it is impossible for epistemic MAVs.

(56)a. Peter said that Max must work for the KGB and [work for the KGB] Max must.

b. Peter said that Max must work for the KGB and [work for the KGB] Max must.

(Drubig, 2001: 31)

(57)a. Opo mbak Jozina oleh [nganggo celono ning pasar]?

Q older sister Jozina may ACT.wear pant to market

'May Jozina wear pants to the market?'

b. [nganggo celono ning pasar], mbak Jozina oleh.

(58)a. Opo mbak Jozina mungkin [nganggo celono ning pasar]?

Q older sister Jozina may ACT. wear pant to market

'Is it possible that Jozina wear pants to the market?'

b. *[nganggo celono ning pasar], mbak Jozina mungkin.

(Guawar, Vander Klok, 2012)

Yanti (2011) further points out that deontic MAVs in Indonesia can not occur sentence-initially, while epistemic MAVs can.

(59)a. *Boleh Ali datang.

May Ali come

'Ali is allowed to come.'

b. Pasti Ali datang.

Certain Ali come

'For sure Ali will come.'

Above all, Deontic MAVs are similar to epistemic MAVs in some aspects but differ in other syntactic features. More evidence shows that deontic MAVs should be divided into two types: direct deontic (subject-oriented) and indirect deontic (proposition-oriented). Eide (2002:23) analyzes the Norwegian deontic and claims that direct deontic MAVs can license pseudo-cleft construction just like dynamic MAVs; while indirect deontic MAVs can't.

(60)a. Det Marit må, er å snakke med ham.

It Marit must is to talk to him. 
'What Marit must (do) is to talk to him.'

b. Det vi alle bØr, er å tenke gode tanker.

It we all should is to think good thoughts

'What we all should (do) is to think good thoughts.'

(61)a. *Det en kvinne bØr, er å bli vår neste statsminister.

It a woman should is to be our next prime minister

'What should happen is that a woman becomes our next prime minister..'

b. *Det apene ikke må, er å mates av besøkende.

It the monkeys not must is to feed-PASS by visitors

'What must not take place is that the monkeys are fed by visitors.'

Asarina \& Holt (2005) also have found that, in Tagalog, direct deontic MAVs can assign NG morpheme to its animated subject, while indirect deontic auxiliary can't and the subject's morphological feature is determined by the complement verb.

(62) Kailangan ng lalaki mawala.

must NG man disappear

'The man must disappear.'

(63)a. *Kailangan ng tinapay mawala.

must NG bread disappear

'The bread must disappear.'

b. Kailangan ang tinapay mawala.

must ANG bread disappear

'The bread must disappear.'

In (62), deontic MAV Kailangan assigns its animated subject lalaki NG morpheme, while in (63), deontic MAV kailangan can't assign NG morpheme to unanimated subject tinapay, and the ANG morpheme is assigned by the complement verb mawala. The distinction between direct and indirect deontic MAVs can be further confirmed by the negation insertion. That is, direct deontic MAVs will reconstruct with its complement verb, so the negation marker "ng" can not be inserted between them. However, indirect deontic MAVs can't reconstruct, so the negation marker "ng" can be inserted.

(64)*Kailangan (ng) [hindi bumili ng lalaki ng kotse.]

must not SA-buy NG man NG car

'The man must not buy a car.' 


\section{Macrothink}

(65)Kailangan (ng) [hindi bumili ang lalaki ng kotse.]

must not SA-buy ANG man NG car

'The man must not buy a car.'

In all, direct deontic MAVs are control verbs which haver semantic constraint, can construct a pseudo-cleft sentence, and can't occur sentence-initially; while indirect deontic MAVs are raising verbs which have no semantic constraints, can't occur in pseudo-cleft construction, and can occur sentence-initially.

\section{Syntactic Hypothesis of MAVs}

\subsection{MAV Cannot Be Raising}

Pullum and Wilson (1977) point out that most MAVare intransitive verbs, similar to the raising verb tend; and only the root MAV dare and will are transitive verbs. However, they notice that the root MAV allowed inanimate subjects.

(66)a. There may be beer and cider at the party, but I refuse to permit spirits in the house.

b. There must be no punching below the belt, and no throttling.

(67)a. These two aspects of death cannot be successfully separated, but they dare not be confused or identified.

b. Inflation is a problem which dare not be neglected.

Thráinsson \& Vikner (1995) suggest that Danish modal auxiliaries should be analyzed as raising verbs, but the raised subject can be assigned an additional theta role. The regulation for its additional theta role is as follows:

(68)a. An argument cannot have more than one additional theta role.

b. Each additional theta role must be assigned to one and only one argument.

c. An additional theta role can be assigned to an argument that already has a theta role.

Examples are as follows:

(69)a. [NP e]

Shall

$(\theta)$ skal

he

$\theta$

'He must enjoy himself.'

b. [NP hani] skal [ti more sigi]. $<\theta,(\theta)>$

Note: theta role is marked as " $\theta$ " and additional theta role is marked as " $(\theta)$ ". 


\section{Macrothink}

In (69), the clause subject han is assigned a theta role in the complement clause, and then is promoted to the main clause and is assigned an additional theta role by the main clause verb. The analysis is based on two phenomena: First, there are two types of event predicates and state predicates in Danish. Event predicates have more implicit meanings than state predicates, so it is assumed that event predicates are assigned to their subject additional theta roles. Epistemic MAVdo not assign the subject additional theta role, and can license event expressions, as in (70); but root MAVs do assign the subject additional theta role, and cannot allow event predicate complement which will assign its subject an additional theta role, as in (71).

$\begin{array}{cccccc}\text { (70)a. Han } & \text { vil } & \text { have } & \text { tre } & \text { biler í } & 1995 \\ \mathrm{He} & \text { will } & \text { have } & \text { three } & \text { cars } & \text { in } 1995\end{array}$

'He will have three cars in 1995.'
b. Han
vil
fá
tre
biler í
1995

He will get three cars in 1995

'He will get three cars in 1995.'

$\begin{array}{cccccc}\text { (71)a. Han } & \text { vil } & \text { have } & \text { tre } & \text { biler í } & 1995 . \\ \text { He } & \text { want } & \text { have } & \text { three } & \text { cars } & \text { in } 1995\end{array}$

'He wants to have three cars in 1995.'
b. *Han vil
fá
tre
biler í
1995.
$\mathrm{He}$
want get
three
cars
in 1995

'intended meaning: He wants to get three cars in 1995.

Besides, blive-passive and s-passive in Norwegian can distinguish between epistemic and root MAVs. The blive-passive type can assign an additional theta role to its subject, so it cannot appear in the complement clause of root MAVs; while the s-passive type doesn't assign an additional theta role to its subject, so can appear in the complement clause of root MAVs.

\begin{tabular}{|c|c|c|c|c|c|}
\hline (72)a. Hun & vil & blive & arresteret & af & politiet. \\
\hline She & will & be & arrested & by & the police \\
\hline \multicolumn{6}{|c|}{ i. 'She will be arrested by the police.' } \\
\hline \multicolumn{6}{|c|}{ ii. '*He wants to be arrested by the police.' } \\
\hline b. Hun & vil & arresteres & af & politiet. & \\
\hline She & wants & be-arrested & by & police-the & \\
\hline
\end{tabular}

'She wants to be arrested by the police.' 
However, Thráinsson \& Vikner also pointed out that the root modal verb kunne "can, be able to" can be used as a complement to other root modal verbs, so it does not meet the additional theta role constraints. Moreover, the continuous use of root modal verbs in other languages is also a common phenomenon. Therefore, the analysis of root MAVas raising verbs based on the additional theta role hypothesis is not without problem.

Wurmbrand (1999) also analyzes deontic modal verbs as raising verbs. First, the deontic MAVs allow the expletive subject, such as (73); and the inanimate noun phrase in their subject position, as in (74). Secondly, in Icelandic, the quirky case of the subject of deontic MAVs is associated with the verb of complement clause, which indicates that the subject is raised to the subject position of the main clause, as in (75).

(73)a. There may be singing but no dancing on my premises.

b. There can be a party as long as it's not too loud.

c. There must be a solution to this problem on my desk, tomorrow morning!

(74) The biscuits may be finished by Paul.

(75) a. Haraldi

Harold-DAT
/*Haraldur

Harold-NOM must verður að Lika hamborgarar.

to like hamburgers

'Harold must like hamburgers (to be accepted by his new American in-laws)'

b. Umsækjandann verður að Vanta peninga.

The-applicant-ACC must to lack money

'The applicant must lack money (to apply for this grant).'

Wurmbrand's analysis shows that the deontic MAVs in the above examples belong to the raising verb, and the object of morality is the whole event. This kind of verb is an indirect deontic modal verb. But not all deontic modal verbs can be analyzed as raising verbs. In Tagalog, the deontic MAVs assigns the subject NG form, even if the complement verb is the SA verb, which indicates that the NG form of the subject of deontic MAVs is not assigned by the complement verb, but the deontic MAV itself, shown as in (76). The indirect deontic MAVs cannot assign the subject any form, and the subject is assigned the ANG form by the complement verb, shown as in (77).

$\begin{array}{cccccc}\text { (76) Kailangan } & \text { ng } & \text { lalaki } & \text { bumili } & \text { ng } & \text { kotse. (direct) } \\ \text { must } & \text { NG } & \text { man } & \text { SA-buy } & \text { NG } & \text { car }\end{array}$

'The man must buy a car.'

$\begin{array}{cccccc}\text { (77) Kailangan } & \text { ang } & \text { lalaki } & \text { bumili } & \text { ng } & \text { kotse. (indirect) } \\ \text { must } & \text { ANG } & \text { man } & \text { SA-buy } & \text { NG } & \text { car }\end{array}$

'The man must buy a car.' 


\section{Macrothink}

International Journal of Linguistics

ISSN 1948-5425

2020, Vol. 12, No. 4

The raising analysis of deontic modal verbs cannot explain the morphological assignment of subjects in Tagalog. What's more, Wurmbrand's analysis ignores the syntactic features of dynamic MAVs, so its argument is not sufficient. On the one side, it cannot account for the subject's Case features in epistemic and dynamic MAV constructions. Thraáinsson \& Vikner (1995: 60) investigate the Danish modal verbs and find that the subject of epistemic MAVs has been checked its Quirky Case (Q-Case) in the complement clause then raises to the main clause as in (78a); while the subject of dynamic MAVs will be checked its nominative Case in the main clause as in (78b).
(78)a. Harald
vill
oft
vanta peninga.

Harold.ACC

will frequently

lack money

'Horald frequently tends to lack money.'

'*Horald frequently wants to lack money.'

$\begin{array}{lllllll}\text { b. Haraldur/*Harald } & \text { vonast } & \text { til } & \text { að } & \text { vanta } & \text { ekki } & \text { peninga. } \\ \text { Harold.NOM/*ACC } & \text { hopes } & \text { for } & \text { to } & \text { lack } & \text { not } & \text { money }\end{array}$

Harold hopes not to lack money.'

On the other side, it cannot explain the inconsistency in deletion and movement of the complement clause in deontic and epistemic constructions. The deontic MAVs allow the subsequent clauses to be deleted or shifted, but the epistemic MAVs are not allowed and must be accompanied by verbs, shown as in (79).

$\begin{array}{rrrrrrr}\text { (79)a. 小明 可能 } & \text { 看了 } & \text { 这本书, } & \text { 小丽 } & \text { 也 } & \text { 可能* } & \text { (看了). } \\ \text { Xiaoming keneng } & \text { kan le } & \text { zhebenshu, xiaoli } & \text { ye } & \text { keneng } & \text { kan le } \\ \text { Xiaoming may } & \text { read Asp } & \text { this CL book } & \text { Xiaoli } & \text { too } & \text { may } & \text { read Asp }\end{array}$

'Xiaoming may have read this book, and Xiaoli may *(have read it) too.'

b. 小明 可以 看这本书, 小丽 也 可以.

Xiaoming keyi kan zhebenshu, Xiaoli ye keyi

Xiaoming is allowed to read this CL book, Xiaoli too is allowed to

'Xiaoming is allowed to read this book, and Xiaoli is allowed to too.'

The analysis of modal verbs as raising verb also cannot explain the scope difference between aspects and MAVs. Many scholars have found that epistemic MAVs can be followed by perfect and continuous aspects, and the semantic scope of epistemic MAVs is higher than the aspect phrase; while dynamic MAV cannot, and their semantic scope is lower than the aspect phrase. (Dyvik, 1999; Yanti, 2011; Lin, 2012)
(80) Han
vil/kan/må/skal
ha dreiet håndtaket. (Norwegian)
$\mathrm{He}$
will/may/must/is
said to have turned the lever 
(81)Han har villet/kunnet/måttet/skullet dreie håndtaket.

$\mathrm{He}$ has want-to/can/must/shall-PERF turn the-lever

(82)a. Maria la

biso nambe?

barajno

(Malaysian)

Maria PRF

can

ACT-take

thing-3

'Maria has been able to take her stuff.'

'Maria has been permitted to take her stuff.'

b. Maria biso la nambe? baranno

'it is possible that Maria has taken her stuff.'

(83)a.小明

可能

[已经

毕业

了].(Chinese)

Xiaoming

keneng

yijing

biye

le

Xiaoming

may

already

graduate

Asp

'Xiaoming may have graduated already.'

b. 张三

应该

[已经

去

上海

了].

Zhangsan

yinggai

yijing

$\mathrm{qu}$

Shanghai

le

Zhangsan

must

already

go

Shanghai

Asp

'Zhangsan must have gone to Shanghai already.'

(84)a. 小明

可以

[看

这本书]

了.

Xiaoming

keyi

kan

zhebenshu

le

Xiaoming

is allowed to

read

this CL book

Asp

'Xiaoming has been allowed to read this book.'

$\begin{array}{lcccccc}\text { b. 他 } & \text { 不 } & \text { 应该 } & \text { [再 } & \text { 做 } & \text { 这件事] } & \text { 了. } \\ \text { Ta } & \text { bu } & \text { yinggai } & \text { zai } & \text { zuo } & \text { zhejianshi } & \text { le } \\ \mathrm{He} & \mathrm{Neg} & \text { should } & \text { again } & \text { do } & \text { this CL thing } & \text { Asp }\end{array}$

'He should not do this again.'

In a word, there is no well-supported evidence for the raising hypothesis of MAVs, by contrast, many inconsistencies between different MAVs stand against it. So the raising and control analysis is a better explanation for the syntactic differences in MAV constructions.

\subsection{On the Raising and Control of MAV Under MP}

The subject raising in epistemic MAV construction has undergone little change as the evolution of generative grammar. In the Minimalist Program (MP), the subject DP of the 


\section{Al Macrothink}

International Journal of Linguistics

ISSN 1948-5425 2020, Vol. 12, No. 4

embedded clause raises to the non-theta subject position of the matrix clause to check the EPP feature of the matrix $\mathrm{T}$, leaves a copy in the original subject position which can be deleted in the following procedure. Following Karimi (2008), we assume that the raising complement of the epistemic MAV is a CP, which will account for some tense and aspect features in the complement clause. What's more, according to Chomsky (2008), TP will not exist in the absence of a local $\mathrm{C}$ since the features of $\mathrm{T}$ are entirely derivative of $\mathrm{C}$ 's features.

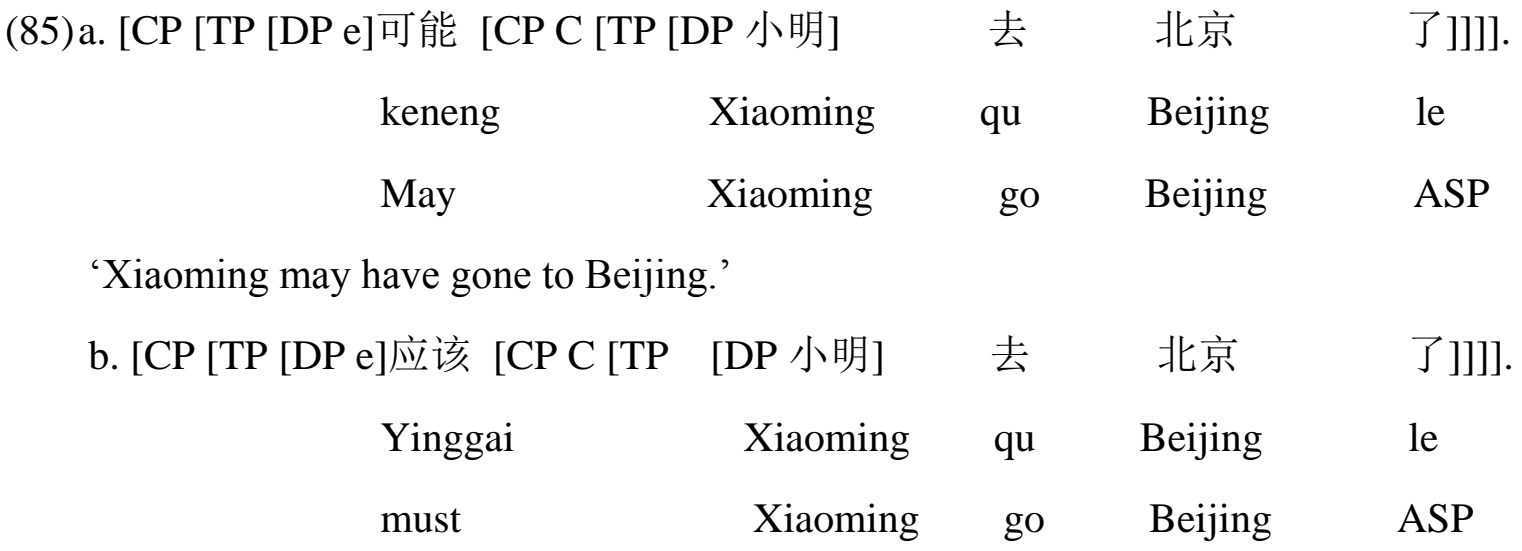

'Xiaoming must have gone to Beijing.'

In the derivation, the DP Xiaoming first merges in the specifier position of the embedded vP satisfying the external theta-role of the embedded verb, then moves to the specifier position of the embedded TP to check the EPP feature of the embedded T. If the embedded clause is finite, the embedded subject can be licensed and will stay in the specifier position of the embedded TP as in (85). Following Lin (2012), we assume that the finite and non-finite distinction in the Chinese embedded clause can be tested by the sentence-final ASP marker le. That is, the semantic scope of epistemic MAVs "keneng, yinggai" is higher than the ASP maker le in finite clauses. The tree diagram of (85a) is shown as follows:

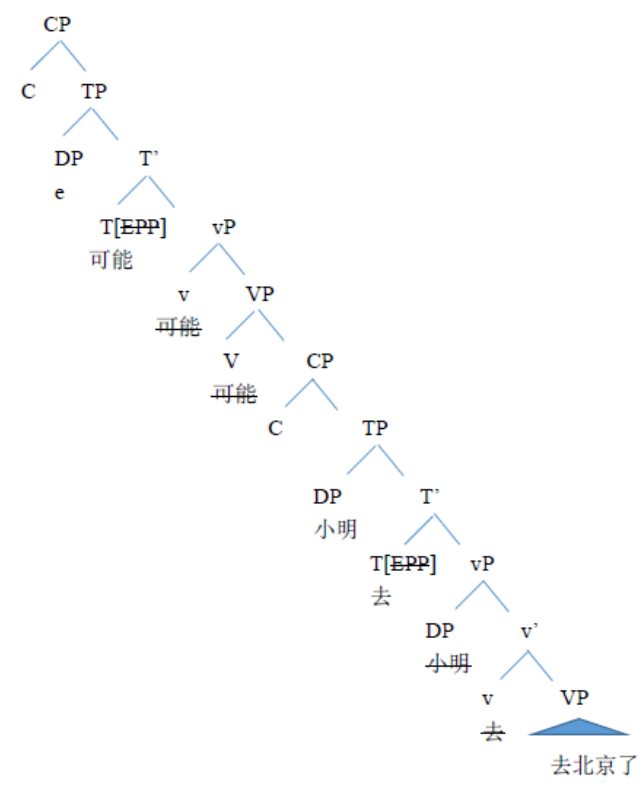




\section{Macrothink}

International Journal of Linguistics

ISSN 1948-5425 2020, Vol. 12, No. 4

In control construction, we follow Landau(2004, 2007, 2008, 2015)'s "agreement model of control", assume that control in MAV construction is interpreted as an Agree relation between a matrix functional $\mathrm{T}$ head and a $\varphi$-bearing element in the infinitive, which can be the infinitival $\mathrm{C}$ or PRO. The matrix functional head $\mathrm{T}$ serves as a probe and agrees with the controller DP, and an Agr-bundle is accessible as a goal on the $\mathrm{C}$ head of the infinitive if and only if the infinitival $\mathrm{C}$ head is a tensed one, then the $\mathrm{C}$-control route is taken, shown as in (87). If the infinitival $\mathrm{C}$ head is untensed and $\varphi$-less, it can not serves as a goal for Agree, then PRO control is the only option, and the $\varphi$-features of PRO can only be valued in the Agree relation with the matrix functional head, shown as in (88).

(87)C-control

$$
\text { T...DP...[CP C }[\varphi][\text { TP PRO }[\varphi] \mathrm{T}]]
$$

(88)PRO-control

$$
\text { T...DP...[CP C [TP PRO }[\varphi] \mathrm{T}]]
$$

Landau also claims that control across a lexical $\mathrm{C}$ can be $\mathrm{C}$-control or PRO-control. In MAV construction, the matrix functional head $\mathrm{T}$ can agree with the infinitival head $\mathrm{C}$ with a [+Tense] feature which values the $\varphi$-features of PRO. Then the $\varphi$-features of infinitival $\mathrm{T}$ is valued by PRO, shown as in (89).

(89) Ta peðjá borún na PRO pro fijun ávrio.

The children BORO-3PL-PRS-IMPRF that leave-3PL+PRS-PRF tomorrow

'The children may/can leave tomorrow.' (Greek, Palmer, 2001: 87)

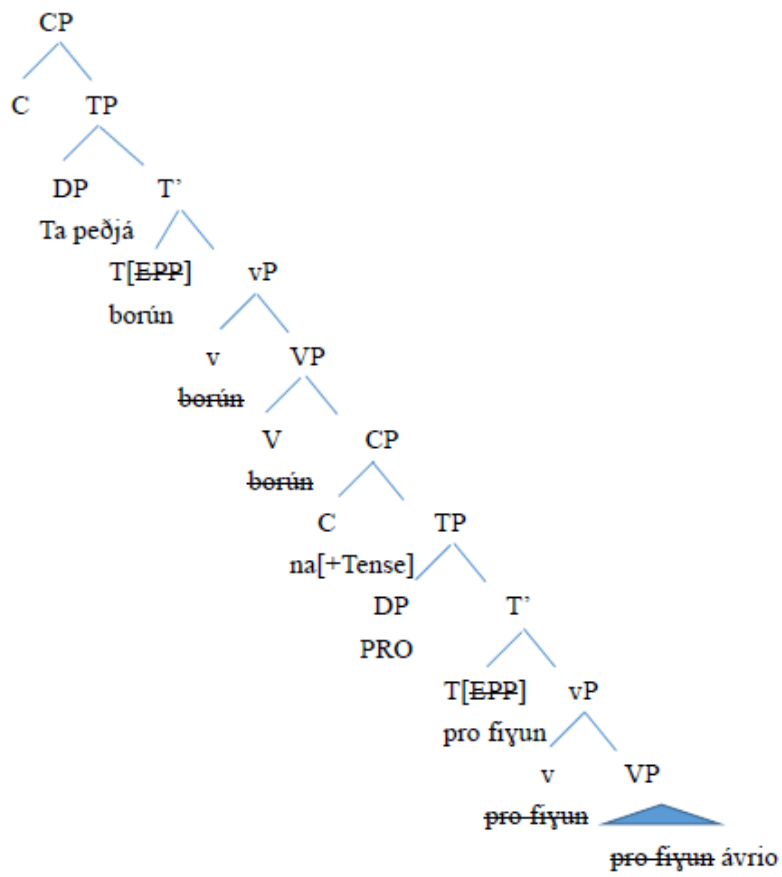




\section{Macrothink}

International Journal of Linguistics

ISSN 1948-5425

2020, Vol. 12, No. 4

While the infinitival clause in Chinese dynamic MAV construction is untensed and is a weak phase, so we assume that the infinitival $\mathrm{C}$ in Chinese has [-tense] feature. Then PRO-control is the only route. In PRO-control, the $\varphi$-features of PRO will be valued by the matrix T, whose $\varphi$-features is valued by the controller DP.

$\begin{array}{rlcc}\text { (91)a. [CP [TP [DP 小明] } & \text { T[肯 [CP C [TP [DP PRO] [T 去 } & \text { 北京] }]]]] \text { 。 } \\ \text { Xiaoming } & \text { ken } & \text { qu } & \text { Beijing } \\ \text { Xiaoming } & \text { is willing to } & \text { go } & \text { Beijing }\end{array}$

'Xiaoming is willing to go to Beijing.'

In the derivation, the DP Xiaoming merges in the specifier position of the matrix $v P$ satisfying the external theta-role of the dynamic MAV "ken", then moves to the specifier position of the matrix TP to check the EPP feature of the matrix T. Since the embedded CP is untensed, the matrix functional head $\mathrm{T}$ cannot agree with the infinitival head $\mathrm{C}$ with a [-Tense] feature. Then matrix functional head $\mathrm{T}$ agrees with the PRO, and checks the $\varphi$-features of PRO. The tree diagram of (91) is shown as follows:

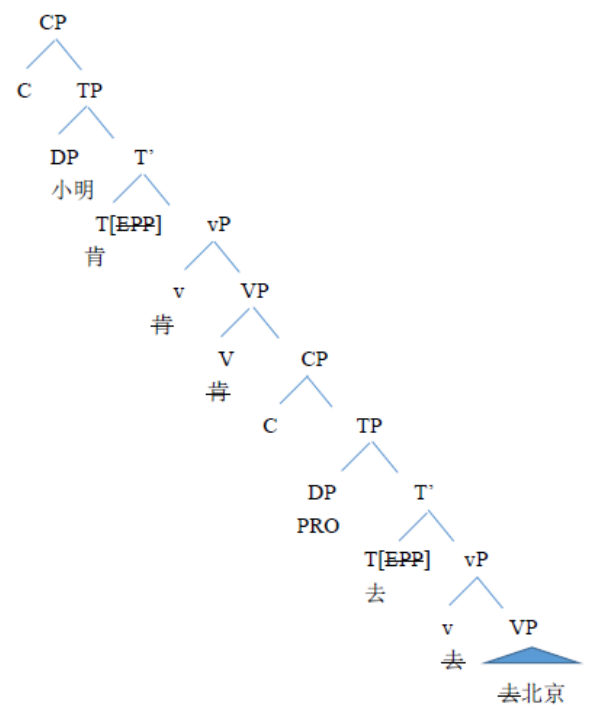

To sum up, the complements of epistemic MAVs can be finite or nonfinite in Chinese, which is distinctive in both embedded subject and object argument movement. Following the agreement model of control, MAVs can be $\mathrm{C}$-control when the embedded $\mathrm{C}$ contains a [Tense] feature, or PRO-control when the embedded $\mathrm{C}$ is untensed. Under this assumption, most of the syntactic features are well explained.

\section{Summary}

In all, MAVs have quite different syntactic features from aspects like semantic constraints, the deletion of the complement clause, constituent movement, pseudo-cleft construction, temporal and aspect markers, etc. So the raising hypothesis of MAVs cannot be right to cover all those differences, and the raising and control hypothesis is the possible solution, that is, 
epistemic MAVs are raising verbs and dynamic MAVs are control verbs. What's more, deontic auxiliary should also be divided into raising and control types considering their systemic differences. However, the syntactic features of MAVs are more complicated than this and some phenomena need further investigation. For example, deontic MAVs in Greek followed by a CP complement may not agree with the matrix subject as in (93).

(93) Ta peðjá eit borí na fiyun ávrio.

The children BORO-3SG-PRS-IMPRF that leave-3PL+PRS-PRF tomorrow

'The children may leave tomorrow.'

(Greek, Palmer, 2001: 87)

The deontic MAV BORO in (93) does behavior like it in (89) which shows dependent agreement in the matrix clause. We assume that there is a null expletive subject in the matrix clause which agrees with the deontic MAV in (92), and the matrix subject Ta peðja raises from the embedded subject position, which indicates that the embedded CP clause is a weak phase and cannot barrier the movement of the embedded subject to the initial position of the matrix clause.

This is similar to Chinese epistemic MAV like 可能 “may” and 应该 “must”, for which embedded subject can stay in the embedded subject position or the matrix subject position as in (94) and (95).

$\begin{array}{rrrrc}\text { (94)a. [CP [TP [DP e]可能 [CP C [TP [DP 小明] } & \text { 去 } & \text { 北京 } & \text { 了]]]]. } \\ \text { keneng } & \text { Xiaoming } & \text { qu } & \text { Beijing } & \text { le } \\ \text { May } & \text { Xiaoming } & \text { go } & \text { Beijing } & \text { ASP }\end{array}$

'Xiaoming may have gone to Beijing.'

b. [CP [TP [DP e]应该 [CP C [TP [DP 小明] 去北京层]]].

$\begin{array}{lllll}\text { Yinggai } & \text { Xiaoming } & \text { qu } & \text { Beijing } & \text { le } \\ \text { must } & \text { Xiaoming } & \text { go } & \text { Beijing } & \text { ASP }\end{array}$

'Xiaoming must have gone to Beijing.'

(95)a. [CP [TP [DP 小明] [DP e] 可能 [CP C [TP [DP 小明]去北京了] ]].

$\begin{array}{ccccc}\text { Xiaoming } & \text { keneng } & \text { qu } & \text { Beijing } & \text { le } \\ \text { Xiaoming } & \text { May } & \text { go } & \text { Beijing } & \text { ASP }\end{array}$

'Xiaoming may have gone to Beijing.'

b. [CP [DP 小明] [TP [DP e]应该 [CP C [TP [DP 小明] 去北京 了] ]]。

$\begin{array}{lcccc}\text { Xiaoming } & \text { Yinggai } & \text { qu } & \text { Beijing } & \text { le } \\ \text { Xiaoming } & \text { must } & \text { go } & \text { Beijing } & \text { ASP }\end{array}$

'Xiaoming must have gone to Beijing.' 


\section{I Macrothink}

International Journal of Linguistics

ISSN 1948-5425

2020, Vol. 12, No. 4

\section{References}

Aelbrecht, L. (2009). You have the right to remain silent: The syntactic licensing of ellipsis. Ph.D. Dissertation. Catholic University of Brussels. https://doi.org/10.1075/la.149

Asarina, A., \& Holt, A. (2005). Syntax and semantics of Tagalog modals. UCLA Working Papers in Linguistics, 12, 1-17.

Benincà, P., \& Poletto, C. (1994). Bisogna and its companions: the verbs of necessity. In G. Cinque, J.-Y. Pollock, L. Rizzi, \& R. Zanuttini (Eds.), Paths towards universal grammar (pp. 35-57). Georgetown: Georgetown University Press.

Bo, H. (2015). Research on the raising and control of Chinese MAVs. Contemporary Linguistics, (2), 1-13.

Brennan, V. (1993). Root and epistemic MAVs. Ph. D. Thesis, Philadelphia: University of Pennsylvania.

Chomsky, N. (1995). The minimalist program. Cambridge, MA.: MIT Press.

Chomsky, N. (2008). On Phases. In R. Freidin, C. Otero, \& M. L. Subizarreta (Eds.), Foundational issues in linguistic theory, essays in honor of Jean-Roger Vergnaud (pp. 133-166). Cambridge, MA: The MIT Press. https://doi.org/10.7551/mitpress/9780262062787.003.0007

Davidsen-Nielsen, N. (1990). Auxiliaries in English and Danish. Papers and Studies in Contrastive Linguistics, 25, 5-21.

Drubig, H. (2001). On the syntactic form of epistemic modality. Tübingen: University of Tübingen.

Dyvik, H. (1999). The universality of f-structure : Discovery or stipulation the case of modals. In M. Butt, \& T. H. King (Eds.), Proceedings of the LFG conference. Stanford, CA: CSLI Publications.

Eide, K. M. (2002). Norwegian modals. Ph.D. Dissertation, Norwegian University of Science and Technology.

Fortin, C. R. (2012). The syntax of 'standard' Indonesian modals. On Proceeding of the 22nd annual conference of the southeast Asian linguistics society. Agay, France.

Karimi, S. (2008). Raising and Control in Persian. In S. Karimi, D. Stilo, \& V. Samiian (Eds.), Aspects of Iranian Linguistics (pp. 177-208). Newcastle upon Thyne: Cambridge Scholars.

Landau, I. (2004). The scale of finiteness and the calculus of control. Natural Language and Linguistic Theory, 22, 811-77. https://doi.org/10.1007/s11049-004-4265-5

Landau, I. (2007). Movement-resistant aspects of control. In W. D. Davies, \& D. Stanley (Eds.), New Horizons in the analysis of control and raising (pp. 293-325). Dordrecht: Springer. https://doi.org/10.1007/978-1-4020-6176-9_14

Landau, I. (2008). Two Routes of Control: Evidence from Case Transmission in Russian. Natural Language and Linguistic Theory, 26, 877-924. https://doi.org/10.1007/s11049-008-9054-0 


\section{I Macrothink}

International Journal of Linguistics

ISSN 1948-5425

2020, Vol. 12, No. 4

Landau, I. (2015). A Two-Tiered Theory of Control. MA: MIT Press. https://doi.org/10.7551/mitpress/9780262028851.001.0001

Lin, T.-H. J. (2012). Multiple-modal constructions in Mandarin Chinese and their finiteness properties. Journal of Linguistics, 48, 151-186. https://doi.org/10.1017/S0022226711000272

LØdrup, H. (1996). Properties of Norwegian auxiliaries. In K. G. OttÓsson (Ed.), Proceedings of the 9th international conference of Nordic and general linguistics (pp. 216-28). Oslo: Novus.

Lyons, J. (1977). Semantics. Cambridge: CUP. https://doi.org/10.1017/CBO9780511620614

Palmer, F. R. (2001). Mood and modality (2nd ed.). Cambridge: CUP. https://doi.org/10.1017/CBO9781139167178

Pullum, G., \& Wilson, D. (1977). Autonomous syntax and the analysis of auxiliaries. Language, 53, 741-788. https://doi.org/10.2307/412911

Roberts, I. (1985). Agreement parameters and the development of the English modal auxiliaries. Natural Language and Linguistic Theory, 3, 21-58. https://doi.org/10.1007/BF00205413

Ross, J. R. (1969). Auxiliaries as main verbs. In W. Todd (Ed.), Studies in philosophical linguistics (pp. 77-102). Evanston: Great Expectations Press.

Thráinsson, H., \& Vikner, S. (1995). Modals and double modals in the Scandanavian languages. In Vikner (Ed.), Working papers in Scandinavian syntax V55 (pp. 51-88).

Vander, K. (2012). Tense, aspect, and modal markers in Paciran Javanese. Ph.D. dissertation, McGill University.

Wurmbrand, S. (1999). Modal verbs must be raising verbs. In Bird, S., A. Carnie, J. Haugen, \& P. Norquest (Eds.), The proceedings of WCCFL (pp. 599-612). Somerville, MA: Cascadilla.

Yanti. (2011). The modal auxiliary Biso 'can' in Jambi Malay. In Proceedings of the international workshop on TAM and evidentiality in Indonesian languages (pp. 65-72). Tokyo: Tokyo University.

Zubizarreta, M. L. (1982). On the relationship of the lexicon to syntax. Ph.D. Dissertation. Cambridge, MA: MIT Press.

\section{Copyrights}

Copyright for this article is retained by the author(s), with first publication rights granted to the journal.

This is an open-access article distributed under the terms and conditions of the Creative Commons Attribution license (http://creativecommons.org/licenses/by/4.0/) 